\title{
Case report of treatment with Icatibant for recurrent throat swelling due to hereditary angioedema
}

\author{
Arthur G Chung ${ }^{*}$, Paul K Keith \\ From Canadian Society of Allergy and Clinical Immunology Annual Scientific Meeting 2010 \\ Victoria, Canada. 3-6 November 2010
}

Department of Medicine, Division of Clinical Immunology and Allergy, McMaster University, Hamilton, Ontario, Canada, L8N $3 Z 5$

We report a 64 year-old woman with longstanding hereditary angioedema who previously required a tracheotomy.

In September 2005, while receiving prophylactic Danazol she noticed a left sided swelling involving her throat and uvula that was of moderate intensity by $1110 \mathrm{~h}$. She came to hospital and received icatibant $30 \mathrm{mg}$ sc at $1330 \mathrm{~h}$ when the swelling was $1 \mathrm{~cm}$ in size. One hour later the swelling was $4 \mathrm{~mm}$ in size. After 2 hours the swelling was gone and did not recur.

Because of increased frequency of angioedema, after December 2008 she started taking C1 esterase inhibitor 2000 PU once weekly, and Danazol $400 \mathrm{mg}$ daily plus additional $\mathrm{C} 1$ inhibitor infusions when symptoms were uncontrolled. She received icatibant in August 2009 for throat swelling. Her symptoms subsided and admission wasn't required. In November 2009, she was admitted for a bowel obstruction due to angioedema. She received a single dose of icatibant, but did not note any benefit. Treatment with icatibant was not repeated. With conservative treatment and additional $\mathrm{C} 1$ esterase inhibitor, her bowel obstruction gradually resolved over 3 days. Her C4 was undetectable $(<0.02 \mathrm{~g} / \mathrm{L})$ and $\mathrm{C} 1$ esterase inhibitor was within the normal range $(0.22 \mathrm{~g} / \mathrm{L}$ normal 0.21-0.39 g/L).

We present a patient with hereditary angioedema whose throat angioedema responded to icatibant but a single dose of icatibant did not have significant effect on bowel angioedema. Physicians should consider icatibant

\footnotetext{
* Correspondence: arthur.chung@medportal.ca

1200 Main St. W. Hamilton Ontario L8N 3Z5, Canada
}

for breakthrough attacks not prevented by prophylactic therapy.

Published: 4 November 2010

doi:10.1186/1710-1492-6-S2-P28

Cite this article as: Chung and Keith: Case report of treatment with Icatibant for recurrent throat swelling due to hereditary angioedema. Allergy, Asthma \& Clinical Immunology 2010 6(Suppl 2):P28.
Submit your next manuscript to BioMed Central and take full advantage of:

- Convenient online submission

- Thorough peer review

- No space constraints or color figure charges

- Immediate publication on acceptance

- Inclusion in PubMed, CAS, Scopus and Google Scholar

- Research which is freely available for redistribution
() Biomed Central 